\title{
Even rules, Uneven Practices: Opening the 'Black Box' of EU Law in Action
}

Citation for published version (APA):

Versluis, E. (2007). Even rules, Uneven Practices: Opening the 'Black Box' of EU Law in Action. West European Politics, 30(1), 50-67. https://doi.org/10.1080/01402380601019647

Document status and date:

Published: 01/01/2007

DOI:

10.1080/01402380601019647

Document Version:

Publisher's PDF, also known as Version of record

Document license:

Taverne

Please check the document version of this publication:

- A submitted manuscript is the version of the article upon submission and before peer-review. There can be important differences between the submitted version and the official published version of record.

People interested in the research are advised to contact the author for the final version of the publication, or visit the DOI to the publisher's website.

- The final author version and the galley proof are versions of the publication after peer review.

- The final published version features the final layout of the paper including the volume, issue and page numbers.

Link to publication

\footnotetext{
General rights rights.

- You may freely distribute the URL identifying the publication in the public portal. please follow below link for the End User Agreement:

www.umlib.nl/taverne-license

Take down policy

If you believe that this document breaches copyright please contact us at:

repository@maastrichtuniversity.nl

providing details and we will investigate your claim.
}

Copyright and moral rights for the publications made accessible in the public portal are retained by the authors and/or other copyright owners and it is a condition of accessing publications that users recognise and abide by the legal requirements associated with these

- Users may download and print one copy of any publication from the public portal for the purpose of private study or research.

- You may not further distribute the material or use it for any profit-making activity or commercial gain

If the publication is distributed under the terms of Article $25 \mathrm{fa}$ of the Dutch Copyright Act, indicated by the "Taverne" license above, 


\section{Even rules, uneven practices: Opening the 'black box' of EU law in action}

\section{Esther Versluis}

To cite this article: Esther Versluis (2007) Even rules, uneven practices: Opening the 'black box' of EU law in action, West European Politics, 30:1, 50-67, DOI: 10.1080/01402380601019647

To link to this article: https://doi.org/10.1080/01402380601019647

册 Published online: 03 Jan 2007.

Submit your article to this journal

Џlll Article views: 1908

Q View related articles ¿

4 Citing articles: 32 View citing articles 


\title{
Even Rules, Uneven Practices: Opening the 'Black Box' of EU Law in Action
}

\author{
ESTHER VERSLUIS
}

While considerable attention is paid to the legal aspect of implementation of European directives, the practical 'street-level' implementation of EU law remains to a large extent a 'black box'. This article sheds light on this black box with a study on the implementation of the Safety Data Sheets Directive in the Netherlands, Germany, the United Kingdom and Spain. This cross-national analysis reveals that different phases in the implementation process leave different traces. Although the member states correctly and completely transposed the directive, compliance by the regulated leaves something to be desired and enforcement by regulators is rare and varies considerably between and within the countries. This article looks into the factors that explain why even rules do not necessarily lead to even practices and argues for more attention for the phase of practical implementation.

'Uneven implementation of EC rules could distort competition across the market quite as much as having no rules at all' (Colchester and Buchan 1990: 132). The main objectives of European integration are unification, uniform rule application and a setting up of equivalent conditions for all member states and therefore of equal competitive positions for all regulated actors. The existence of such uniform rule application depends on the way in which these rules are implemented across the European Union.

Studies on implementation of European legislation are numerous, yet rather 'narrow' in perspective. According to Hill and Hupe (2002: 127), what is called 'implementation' in those studies in fact could be seen as 'policy formation'. Taking it one step further, it can be argued that most studies focus on the legal aspect of implementation. Whereas considerable attention is paid to transposition into domestic legislation (the 'law in the books'), the practical implementation (the 'law in action') remains to a large extent a 'black box'. There is relatively little insight into how European 
legislation is applied in practice, that is, how regulators enforce it and how the regulated comply with it. This article will, via cross-national comparison of the implementation of one specific directive, demonstrate that when analysing implementation of European legislation, it is essential to pay more attention to this 'black box' of practical implementation. Insight into the contents of this box shows that different phases leave different traces. Different notions of implementation generate different results; a directive can be perfectly transposed into national legislation, but this does not necessarily lead to practical implementation as well. This article pleads for a more cautionary use of the concept 'implementation'.

The case studied in this article is the Safety Data Sheets Directive of 5 March 1991 (91/155/EEC), regulating a safe handling of dangerous substances and preparations. ${ }^{1}$ Its implementation is studied in four member states: the Netherlands, the United Kingdom, Germany and Spain. ${ }^{2}$ These four countries have been selected based upon presumed differences in regulatory styles. Within the European Union, Germany and the United Kingdom are often depicted as two extremes: 'Regarding the dominant regulatory style, Germany approaches the interventionist ideal type whereas Britain reflects the mediating type more closely' (Knill and Lenschow 1998: 597). The Dutch approach to regulation can be situated in the middle, with German rules and British application (Haverland 1999) and Spain has been selected because of its reputation as a non-complier (e.g. La Spina and Sciortino 1993; Pridham and Cini 1994).

The article starts with an analysis of the concept 'implementation' and an overview of implementation research. Hereafter, the implementation of the Safety Data Sheets Directive is analysed in terms of transposition, enforcement and compliance. The variation brought to the light by this cross-national comparison is explored in the next section. The article concludes with an overview of the consequences of these empirical insights into the black box of practical implementation.

\section{Analysing Implementation}

\section{What is 'Implementation'?}

The general understanding of the concept 'implementation' is 'to carry out, accomplish, fulfil, produce, complete' (Hill and Hupe 2002: 3); in this example, it is the carrying out of policy decisions. It has to be kept in mind that implementation should be distinguished from related concepts such as compliance and effectiveness. Effectiveness refers to 'the efficacy of a given regulation in solving the political problem' (Neyer and Zürn 2001: 4). Perfect implementation can exist without this being effective, that is, without it solving the problem at stake. Compliance can be defined as the extent to which 'agents act in accordance with and fulfilment of the prescriptions contained in ... rules and norms' (Checkel 1999: 3). In order to comply with 
European policy commitments, implementation is often required, but it is not an absolute necessity. Compliance can occur without implementation, for example when there is a complete 'fit' between the domestic practice and the accord. In the context of the European Union there are several 'notions of implementation' (see Table 1); the concept is used for a variety of elements of, or phases in, the EU policy process. Different scholars refer to different aspects when analysing implementation, which can potentially lead to misunderstandings and confusion.

Since both European and national actors have 'implementing tasks', a first misunderstanding that can arise is whether one refers to implementation on the European level or on the member state level. On the European level, the European Commission is involved in several activities that can be labelled under 'implementation'. A first responsibility of the Commission is that it, according to Article 211 (Treaty Establishing the European Community, TEC), is the 'guardian of the treaties'. As guardian, the Commission is, together with the European Court of Justice and via the infringement procedure (Article 226, TEC), responsible for ensuring the proper application of EU legislation in all member states. Secondly, Article 202 (TEC) also refers to implementing powers of the Commission (e.g. Neuhold 2001). This article refers to the activities commonly known as 'comitology', during which committees composed of member state officials advise, block or approve the Commission's proposals for implementing - i.e. filling in details and incomplete gaps of - EU legislation. A third and last reference to implementation concerns the Commission's tasks in directly overseeing application of European legislation in specific policy fields. Most important is the field of competition (Article 85, TEC), where the Commission can, for example, directly prevent mergers from taking place. These direct implementation tasks of the Commission are exceptional, however, and generally speaking implementation of European legislation is the responsibility of the member states. Even though the Commission acts as the 'guardian of the treaties', Article 10 (TEC) specifies that it is the member states that need to ensure fulfilment of European commitments.

What precisely member states have to do to implement EU rules depends on the type of rule that is issued. Of the three binding European policy instruments, 'regulations' and 'decisions' are directly applicable while

TABLE 1

NOTIONS OF IMPLEMENTATION

\begin{tabular}{lc}
\hline European level & Member state level \\
\hline$\checkmark$ The Commission as the & $\checkmark$ Formal implementation, i.e. transposition: \\
'guardian of the treaties' & the 'law in the books' \\
$\checkmark$ Comitology & $\checkmark$ Practical implementation, i.e. enforcement \\
$\checkmark$ Direct implementation by the Commission, & by regulators and compliance by regulated: \\
e.g. in the field of competition & the 'law in action' \\
\hline
\end{tabular}


'directives' are only binding on the results to be achieved (Article 249, TEC). Especially in the example of directives, confusion can arise as to what is meant by the word implementation. Often a distinction is made between 'formal' or 'legal' implementation on the one hand and 'practical' or 'administrative' implementation on the other hand (e.g. From and Stava 1993; Pridham and Cini 1994). By formal or legal implementation (judicial interpretation) the transposition of European directives into national legislation is meant: the 'law in the books'. Obviously, this understanding of implementation as transposition does not relate to regulations and decisions as they are directly applicable. Practical or administrative implementation (socio-political interpretation) rather refers to the establishment of administrative agencies, the setting up of necessary tools and instruments, monitoring and inspecting by regulators (i.e. enforcement) and the actual adherence to the law by the regulated (i.e. compliance ${ }^{3}$ ). This understanding of the word implementation concerns the 'law in action'.

This article analyses implementation of a European directive on the member state level and therefore does not touch upon notions of implementation at the European level. The policy instrument 'directive' is selected as it most clearly illustrates the variety of tasks that member states undertake when implementing European legislation.

\section{Implementation Studies in the EU}

Following the American tradition in implementation literature (e.g. Pressman and Wildavsky 1973; Sabatier and Mazmanian 1979), the first real empirical study of the European situation by Siedentopf and Ziller (1988) set the scene for a wide range of EU implementation research. Reviewing the last two decades, Mastenbroek (2005) 'maps the field' in three waves (see also Falkner et al. 2005: 14-22). The first scholars studying implementation on the European level came from a variety of disciplinary backgrounds, combining legal variables (such as the quality of EU legislation and the complexity of national legal systems), administrative explanations (such as internal coordination problems or a lack of resources) and political causes (such as the role of parliaments and interest groups). ${ }^{4}$ Change in focus came with the so-called second wave influenced by the Europeanisation school. Mainly analysing the environmental field, scholars emphasised the impact of the degree of fit or misfit between the European legislation and the domestic circumstances (e.g. Börzel 2003; Cowles et al. 2001; Héritier et al. 2001). The compatibility between the EU rule and the domestic situation, and the available mediating factors, help to explain the likeliness of implementation success. As several studies demonstrated the limited explanatory power of the goodness-of-fit hypothesis (e.g. Haverland 1999; Knill and Lenschow 1998), Mastenbroek argues further that the third and most recent wave in researching EU compliance shows 
the need to bring domestic politics (such as the embeddedness of institutions and the policy context) back into our explanations (Mastenbroek 2005: 1110).

While the range of variables to explain differing implementation of European legislation is enormous (from legislative complexity, to administrative constraints, and veto players), ${ }^{5}$ less variance is found in the object of study. Most empirical studies on EU implementation concentrate mainly on the phase of formal implementation, the transposition (e.g. Bursens 2002; Dimitrakopoulos 2001; Mastenbroek 2003; Pappas 1995; Siedentopf and Ziller 1988). ${ }^{6}$ Despite some exceptions (e.g. Demmke 2001; Falkner et al. 2005; Versluis 2003), questions of practical implementation are still largely ignored. While this is very well explicable by the fact that data on practical implementation are hard to obtain, this does not weaken the conclusion that we need to aim at 'broadening our scope to the stages of application and enforcement' (Mastenbroek 2005: 1114). In the next section, an insight into the implementation of the Safety Data Sheets Directive will shed further light into the black box of EU law in action. Which of the categories of factors identified in EU implementation research seem to play a role in analysing practical implementation in this specific case?

\section{EU Law in Action: The Safety Data Sheets Directive}

The Safety Data Sheets (SDS) Directive regulates that persons responsible for placing dangerous substances and preparations on the market must supply the professional recipients (e.g. manufacturers, importers or distributors) with information - in the form of a 'safety data sheet' - on how to deal with these dangerous substances and preparations. ${ }^{7}$ These measures for safe handling of dangerous products must be presented in 16 prescribed headings (usually four to six pages), including information such as composition and ingredients, first aid measures or information on handling and storage. For example, a safety data sheet for 'chlorine dioxide' should list, under heading six, accidental release measures, that personal precautions should be to wear a gas mask, safety goggles and safety gloves when dealing with major spills and that possible sources of ignition must be removed. In order to analyse how this directive is applied in practice, all different notions of implementation on the member state level are examined: how is the directive transposed into national legislation, how is it enforced by inspectors and how do those regulated comply with the obligation to supply safety data sheets for dangerous substances and preparations?

\section{Transposition}

The Safety Data Sheets Directive was adopted on 5 March 1991 and needed to be transposed by the member states on 30 May of that same year. 
The transposition time thus was less than three months; a rather unusual situation since usually directives allow - and member states need - about two years for incorporating the new European requirements into domestic legislation. Considering this short time period, it is not surprising that all four member states (the Netherlands, Germany, the United Kingdom and Spain) were about two years late with their transposition. Via its role as 'guardian', the European Commission could have decided to start the infringement procedure against the member states for not transposing on time. The Commission did not do so as it realised that the time period allowed for transposition was too short. In none of the member states was the delay caused by particular problems related to the directive and seems to have mainly arisen because of a lack of time.

The four countries all used secondary legislation to transpose the directive and three of the four member states - Germany being the exception - used new instead of already existing legislation. When comparing the text of the European directive with the texts of the national transpositions, it can be observed that the national legislation in all four countries almost literally uses the wording of the directive. Transposition can therefore in general be characterised as late, but correct and complete. In all four countries transposition was a rather smooth process, where only the transposing actor was involved and third parties such as parliaments, industry or sub-national governments (e.g. German Länder or Spanish Autonomous Communities) held aloof from participation (see Table 2).

The main difference that can be observed between the four member states is that the Netherlands chose to devote a separate piece of legislation to the topic of safety data sheets and decided to make the annex of the directive,

TABLE 2

TRANSPOSITION

\begin{tabular}{|c|c|c|c|}
\hline $\begin{array}{l}\text { Member } \\
\text { state }\end{array}$ & $\begin{array}{l}\text { Date of } \\
\text { transposition }\end{array}$ & National legislation & Transposing actor \\
\hline Netherlands & April 1993 & $\begin{array}{l}\text { Veiligheidsinformatiebladenbesluit } \\
\text { Wet milieugevaarlijke stoffen }\end{array}$ & $\begin{array}{l}\text { Ministerie van Sociale } \\
\text { Zaken en } \\
\text { Werkgelegenheid }\end{array}$ \\
\hline Germany & October 1993 & Gefahrstoffverordnung & $\begin{array}{l}\text { Bundesministerium } \\
\text { für Arbeit und } \\
\text { Socialordnung }\end{array}$ \\
\hline $\begin{array}{l}\text { United } \\
\text { Kingdom }\end{array}$ & September 1993 & $\begin{array}{l}\text { The Chemicals (Hazard } \\
\text { Information and } \\
\text { Packaging for Supply) } \\
\text { Regulations }\end{array}$ & $\begin{array}{l}\text { Health and Safety } \\
\text { Commission }\end{array}$ \\
\hline Spain & July 1993 & $\begin{array}{l}\text { Real Decreto } 1078 / 1993 \text {, } \\
\text { de } 2 \text { de julio, por el que } \\
\text { se aprueba el reglamento } \\
\text { sobre clasificación, } \\
\text { envasado y etiquetado de } \\
\text { preparados peligrosos }\end{array}$ & $\begin{array}{l}\text { Ministerio de Sanidad y } \\
\text { Consumo }\end{array}$ \\
\hline
\end{tabular}


which describes the content of the 16 headings of a sheet, obligatory. In the other three member states, the SDS Directive has been transposed into national legislation that regulates multiple topics. In the United Kingdom, for example, the sheets are integrated into one regulation that also deals with classification, labelling and packaging of dangerous substances and preparations. In addition, the other three member states decided to, as the directive does, use the term 'guide' for the annex of the directive, while the Dutch legislation states that the sheets must meet the requirements as they are laid down in the annex.

\section{Enforcement}

Transposition alone does not tell the entire 'implementation story'. A European directive can be perfectly transposed into national legislation, as is the case with the Safety Data Sheets Directive, but this does not yet say anything about practical implementation. To what extent does enforcement take place? In order to enforce the SDS Directive, inspectors have to check whether companies that house dangerous substances and preparations have safety data sheets available for these products. Each sheet needs to use the right (national) language, have 16 headings and show the correct content of these headings. Besides, inspectors have to check whether companies regularly update their sheets to the latest scientific and technological knowledge and whether they comply with the demand to deliver the sheets with every first supply of a product. The extent to which inspectors actually carry out such activities differs considerably between, and within, the four member states (see Table 3).

In the Netherlands, the 'Inspectie Milieuhygiëne' ('Inspectorate for the Environment' $)^{8}$ is the main agency that enforces the SDS Directive. ${ }^{9}$

TABLE 3

ENFORCEMENT

\begin{tabular}{|c|c|c|c|c|}
\hline $\begin{array}{l}\text { Member } \\
\text { state }\end{array}$ & Enforcing actor & Active enforcement? & $\begin{array}{l}\text { Inspection } \\
\text { tools }\end{array}$ & $\begin{array}{l}\text { Organisation of } \\
\text { the enforcement }\end{array}$ \\
\hline Netherlands & $\begin{array}{l}\text { 'Inspectie } \\
\text { Milieuhygiëne' }\end{array}$ & $\begin{array}{l}\text { Annual inspection } \\
\text { projects }\end{array}$ & Yes & Rule-oriented \\
\hline Germany & $\begin{array}{l}\text { 'Staatliches Amt für } \\
\text { Arbeitsschutz' or } \\
\text { 'Gewerbeaufsichtamt' }\end{array}$ & One project only & No & $\begin{array}{r}\text { Company- } \\
\text { oriented }\end{array}$ \\
\hline $\begin{array}{l}\text { United } \\
\text { Kingdom }\end{array}$ & $\begin{array}{l}\text { 'Health and } \\
\text { Safety Executive' }\end{array}$ & One project only & No & $\begin{array}{l}\text { Company- } \\
\text { oriented }\end{array}$ \\
\hline Spain & $\begin{array}{l}\text { 'Consejería de Sanidad' } \\
\text { (Madrid; similar actors } \\
\text { in other Autonomous } \\
\text { Communities) }\end{array}$ & $\begin{array}{l}\text { Semi-active in } \\
\text { Madrid and } \\
\text { Andalusia; } \\
\text { Nothing in } \\
\text { Catalonia and } \\
\text { Valencia }\end{array}$ & No & Rule-oriented \\
\hline
\end{tabular}


This Inspectorate is a rather hierarchical organisation that is sub-divided into five, centrally steered, regions. In each of these regions two inspectors are responsible for hazardous substances. Thus, in total, ten Dutch inspectors spend a small percentage of their time on SDS enforcement. Within the environmental inspectorate, enforcement is organised in special, rule-oriented projects and the topic of safety data sheets is integrated into projects on 'hazardous substances'. In the period 1997-2001, the data sheets were, always in combination with other hazardous substances legislation, subject to three inspection projects. During these projects, the inspectors were obliged to use a standardised inspection and sanctioning tool: the 'Enforcement Execution Method' (Inspectie Milieuhygiëne 1999a). This method describes the various steps to be taken by the inspector from preparation, to inspection, to 'after-care'. For each of these phases, a computerised 'to-do' checklist guides the inspector through the process. The method also describes possible infringements and their complementary sanctions. For example, when a sheet is missing, the environmental inspector is expected to issue both a warrant and a penalty.

During these projects, the inspectors adopted a rather legalistic enforcement style: infringements were reprimanded via a letter indicating the intention to impose a penalty if the infringement were not reversed. A copy of this letter was also sent to third parties such as the municipality. As the Dutch projects discovered that compliance results were not very positive (see the next section on compliance), the project leader responsible for hazardous substances policy decided that the data sheets would remain a part of future projects, at least in the near future. Due to the highly centralised organisation of the Inspectorate, it was possible for this one project leader to ensure that the data sheets were on the 'enforcement agenda' in the entire country.

In Germany, enforcement of legislation is delegated to the Länder, and thus there are potentially 16 different 'enforcement systems'. ${ }^{10}$ While NorthRhine Westphalia uses its 'Staatliches Amt für Arbeitsschutz' ('Regional Agency for Labour Protection') for the enforcement of the SDS Directive, Baden-Württemberg and Bavaria both use their 'Gewerbeaufsichtamt' ('Factory Inspectorate'). In all three Länder there are approximately 500 inspectors who can potentially visit companies to check their data sheets. In practice, however, these inspectors rarely do so. Each of the three cases show the same pattern. After the introduction of the directive, one special project was organised to check the data sheets: in North-Rhine Westphalia in 1995 and in both Baden-Württemberg and Bavaria in 2000. After (and before) this one special project, enforcement of the SDS Directive became an individual responsibility of the inspectors. Due to the company-oriented organisation of the enforcement, inspectors have considerable discretion; they are responsible for a geographical area or a number of companies where they check all legislation for which their agency is responsible. As the inspectors have a large amount of legislation to check, the attention paid to 
safety data sheets depends on their time and interest, which can generally be considered 'limited'.

The enforcement pattern in the United Kingdom resembles the German case. Although, contrary to the federalised organisation in Germany, enforcement is nationally organised: the 'Health and Safety Executive' is responsible for checking the data sheets for the entire country. ${ }^{11}$ Similar to Germany, however, are the company-oriented approach and high discretion of the inspectors. Here as well, each of the more than 700 inspectors is responsible for his or her set of companies and checks all occupational safety and health legislation in these companies. The amount of attention paid to safety data sheets thus depends on the individual inspector. While the Executive also organised one specific project on checking the SDS Directive in one part of the country (Northern Region Project in 1997-98), attention to this topic during regular inspections is negligible. As one inspector said, 'safety data sheets are not on top of everyone's list of things to do and not very much attention is paid to the enforcement of it'. ${ }^{12}$

As in Germany, enforcement is a delegated responsibility of the Autonomous Communities in Spain. ${ }^{13}$ Whereas in Germany there is little difference between the Länder in how they (do not) enforce the SDS Directive, in Spain there are differences between various communities in the amount of attention paid to safety data sheets. In all four Autonomous Communities, the 'regional health ministry" ${ }^{14}$ - and in particular the department on environmental health - is responsible for enforcement. Only two of the four communities, however, actually enforce the SDS Directive. In Madrid safety data sheets are checked by 22 inspectors as a part of a larger project to establish a database containing companies with "chemical risks'. In 2002, Andalusia began to set up a programme on chemical products of which the sheets form a part. Enforcement is expected to take place in the future when the 300 health inspectors are trained. The situation in Catalonia and Valencia resembles the German and British cases where attention to safety data sheets depends on the individual inspector and is lacking in most cases.

None of the four member states undertakes rigorous inspections of safety data sheets. In three of the four countries many inspectors could enforce this, but they only spend a negligible proportion of their time on this task (apart from the few inspectors per country who consider it important and dedicate more of their time to checking data sheets). The Netherlands forms a somewhat more positive exception to this rule, however. It is the only country that established an obligatory inspection tool and that arranges regular enforcement projects during which environmental inspectors carry out thorough checks on the content of the data sheets and sanction those who do not comply. And even here, given the enormous amount of substances and preparations on the European market, the impact that only ten inspectors can have on the thousands of Dutch companies that need to have safety data sheets is questionable. Also Madrid and Andalusia now 
pay more regular attention to this topic, but focus more simply on the presence of sheets and, up until now, make considerably less thorough checks on the content of the sheets. One can conclude that the enforcement of the SDS Directive is not high on everyone's agenda.

\section{Compliance}

When correctly transposed, a lack of enforcement does not necessarily indicate a lack of practical application of a European directive. Enforcement does not need to take place when there is perfect compliance by the regulated. When companies supplying dangerous substances and preparations have safety data sheets containing accurate information, there is no need for intensive enforcement in order to ensure that 'practical implementation' takes place. Available information, however, shows that compliance with the Safety Data Sheets Directive is not always perfect.

The various specific enforcement projects on safety data sheets demonstrate that the level of compliance leaves something to be desired. Safety data sheets was the subject of one Europe-wide inspection project on dangerous substances, coordinated by the Netherlands. In this project SENSE ('Solid Enforcement of Substances in Europe') in 1996-97, 1,905 substances were checked in 100 companies. Safety data sheets were available for only 66 per cent of the substances and of these 20 per cent were incorrect (Ministry of Housing, Spatial Planning and Environment 1998). The various inspection projects organised by the Dutch 'Inspectorate for the Environment' also show considerable deficiencies (Inspectie Milieuhygiëne 1999b, 2000a, 2000b). During the first project where 336 substances and preparations were checked, only one data sheet was missing. Yet, when analysing the content of the 16 headings, only 14 per cent of these data sheets were rated as sufficient. The second project in trading companies showed that 119 of the 120 data sheets were present, but only 29 per cent of these had complete and correct content. During the last project, 13 of the 16 inspected companies showed infringements. Not only in the Netherlands are bad results shown. In Germany, too, the project in Baden-Württemberg showed that data sheets were present in only 58 per cent of the 237 inspected companies (Umweltministerium Baden-Württemberg 2000). While no empirical results are available, a representative of the Spanish chemical industry association 'Feique' argues that Spain has particular problems with the SDS legislation. ${ }^{15}$ As a large percentage of the chemical industry consists of smaller and medium-sized companies that receive their products, and thus data sheets, from foreign suppliers, most are available in English. In order to comply with the obligation to provide the data sheets in the national language, many companies use automatic translators. These translated sheets are of poor quality as the automatic translators produce incomprehensible sentences and especially smaller companies lack the expertise to improve these translations. 


\section{Even Rules, Uneven Practices: An Analysis of the Variation}

When opening the 'black box' of implementation, it can be seen that different notions of implementation generate different results. Implementation of the Safety Data Sheets Directive in the understanding of transposition shows similar, uniform results across the member states. Although too late, all member states did eventually correctly and literally transpose the directive into national legislation. The literal translation is no surprise since the directive is based on Article 94 (TEC) and is thus a 'maximum' directive, implying that during the transposition member states are not allowed to add any deviating elements that contain a change of the technical requirements. The findings for this particular directive correspond to earlier empirical results on transposition stating that the Netherlands, the United Kingdom and Spain often use secondary legislation, that the United Kingdom and Spain often literally copy the text of directives and that Germany shows a tradition of using existing legislation for its transposition (La Spina and Sciortino 1993; Siedentopf and Ziller 1988).

Turning to the practical implementation, the outcomes are more diverse. While compliance results are not very promising, enforcement is rare and varies considerably across and within the four countries. Why do even rules not lead to even practices?

\section{Non-compliance: The Impact of Issue Salience}

While the variation in regulatory styles between the countries as mentioned in the introduction do not seem to play a particular role, ${ }^{16}$ what factors explain why the SDS Directive is applied so badly in practice; what shapes the negative responses of the four member states to the obligation to implement this directive? Without claiming to touch upon all variables identified in two decades of EU implementation research, the main categories of explanations offered do not seem to hold in this specific case. First of all, the many legal variables identified (e.g. Krislov et al. 1986; Tallberg 2002) - such as the complexity and poor quality of EU legislation do not apply to the very clear and straightforward SDS Directive. Apparently the assumption that directives with clear and reasonable goals 'in theory are at least more readily susceptible to monitoring and enforcement' (Somsen 1996: 11) is indeed a theoretical assumption. Nor do administrative explanations (e.g. Chayes and Chayes 1993; Cowles et al. 2001) - such as a lack of resources or facilitating institutions - seem to do the trick. In none of the four member states are indicators present that point to a lack of financial or administrative resources. Institutional capacities are sufficient, as the appropriate structures are in place to, at least in theory, ensure enforcement. In addition, none of the countries show an apparent misfit between the requirements in the directive and the existing domestic institutional framework. Is the explanation to be found in the more 
rationalist argument of 'opposition through the backdoor' (Falkner et al. 2005: 277)? As none of the four member states indicate a protest against defeat in the EU decision-making process, this argument is also not applicable in the SDS case.

What seems to be at stake is a factor indicated to have become more important in the third wave of EU compliance research as identified by Mastenbroek (2005: 1110): policy or issue salience. Issue salience in general terms refers to the visibility of and the importance attached to a topic and it is assumed that visibility of an issue conditions behaviour (Roberts et al. 2002). Salience is of particular importance in practical implementation as the number of regulations that inspectors have to enforce is enormous. Generally speaking, enforcement agencies are accountable for more regulations than the number of inspectors available can ever check. Choices have to be made. Noordegraaf (2000) describes these choice-making processes as the 'distribution of attention'. ${ }^{17}$ According to Kingdon (1995: 93), the reason why some issues are picked up and why others are ignored is to a large extent to be found in focusing events that push problems on to the agenda or drive them into 'greater prominence'.

The SDS Directive is a rather invisible directive and there do not seem to have been 'focusing events' to push it on to the agenda of enforcement agencies. In none of the four member states did the topic of safety data sheets ever receive media attention, nor was the topic of this directive ever associated with dramatic events such as accidents or crises. Both inspectors and chemical companies indicate that of all legislation that requires attention, the data sheets do not stand out. A British inspector stated that 'some regulations clearly can't be avoided and are pushed for by our management as nowadays is the case with COMAH. I tried to push for more national attention for the sheets as well, you know, but when COMAH came along all minor topics had to be pushed aside'. ${ }^{18}$ Despite the negative compliance results, the low visibility and unpolarised nature of the directive seem to influence enforcement practices. Knill's assumption seems to be reality in the SDS case: 'If political salience is low, we assume that perception of adaptation pressure shifts from a moderate to a low level. Due to political indifference, policy problems addressed by supranational legislation are either overlooked, neglected, or taken as being satisfactorily resolved by given administrative arrangements' (Knill 1997: 11).

\section{Why Comply?}

As the low salience of the Safety Data Sheets Directive is an issue that concerns all member states, the question is how it can be explained that the Netherlands shows a somewhat more pro-active approach in enforcing this topic. Dutch inspectors also have to make choices and distribute their attention; why do they devote (some of) their attention to this 'minor' topic? Three elements differ in the Netherlands compared with the three other 
countries that seem to explain why the Netherlands does comply despite the low salience of the directive.

The first element is what Falkner et al. (2005: 313) describe as 'issue linkage'. In the other three member states, during the transposition the topic of safety data sheets was 'linked' to other issues such as classification and packaging of substances. While Falkner et al. convincingly show that issue linkage can lead to negative impacts such as a delay in transposition or conflict, the SDS case seems to hint that issue linkage could potentially also lead to invisibility of a topic when linked to more salient issues. The Dutch choice to transpose the directive on its own, and to make the status of the annex of the directive obligatory, might have made the directive slightly more visible compared to the other member states, thereby positively influencing enforcement opportunities.

The second element on which the Dutch situation differs is the presence and extensive use of an obligatory inspection and sanctioning tool. Bovens and Zouridis argue that the presence of computerised enforcement tools is likely to influence the discretion of inspectors and in turn the legality of the inspection style: 'ICT makes it possible to perfect the legality of the execution in the extreme. Such detailed structuring is possible that even in the assessment of individual cases, as it were, no derogation from the rules can be made' (Bovens and Zouridis 2002: 17).

The third element is the institutional organisation of the enforcement. As enforcement is a choice-making process where attention needs to be distributed, it seems to make a difference to what extent the inspectors have discretionary freedom. The Dutch environmental inspectorate organises enforcement differently compared to Germany and the United Kingdom. In this inspectorate, project leaders decide on specific rule-based projects and due to the high centralisation of the organisation they determine what legislation all Dutch inspectors will enforce. In Germany and the United Kingdom, enforcement is company-based, implying that inspectors have their own set of companies and relatively high discretion as to which legislation they concentrate on while inspecting these companies. This has an impact on the enforcement of a non-salient topic; when inspectors can themselves select inspection topics it is unlikely that they will select a less visible and salient topic. ${ }^{19}$

\section{Theoretical Implications of the SDS Case}

While this one-case study does not claim to develop a solid theoretical framework explaining implementation of European legislation, this case does highlight some relevant theoretical implications. The Safety Data Sheets Directive seems to indicate the importance of issue salience. While solutions to explain the lack of practical implementation would not be found in the complexity of the directive, administrative incapabilities, misfit or opposition, issue salience does seem to provide an explanation. 
Member states do not enforce or comply with the SDS Directive, simply because it is not considered to be important enough. This case study suggests that for salient topics the central question remains why enforcement and compliance do not occur. For a non-salient topic, however, this question must be reversed: as non-enforcement and non-compliance seem to be the 'natural state of affairs', variables ought to be provided to explain why enforcement and compliance do sometimes occur. Here the Dutch example indicates that issues that are not considered to be important win in 'enforcement opportunities' when a centralised, rule-based enforcement structure and computerised inspection and sanctioning tools reduce the discretionary freedom of inspectors and thus 'force' inspectors to concentrate on the less visible topics.

The observation might be justified that opportunities for non-salient cases to be enforced increase when a classical 'top-down' approach is taken. The question is whether this is also necessary to ensure enforcement of more salient issues. Before this rather 'top-down' observation can become a solid conclusion, we are in need of further implementation research that takes a case selection based on issue salience into account.

\section{Final Remarks}

The empirical conclusions of the safety data sheets case show that formal implementation, transposition, took place in a rather uniform manner; the Netherlands, Germany, the United Kingdom and Spain all, albeit rather late, completely and correctly transposed the Safety Data Sheets Directive into national legislation. Practical implementation, however, did not automatically follow. Although some countries demonstrate more attention than others, enforcement of this directive cannot be considered intensive. Nor can compliance by companies be characterised very positively. All in all, while formal implementation takes place, the practical implementation leaves something to be desired. The SDS case shows that the 'law in the books' does not automatically lead to the 'law in action'. Implementation of European directives in reality leads to even rules and uneven practices. Conclusions connected to this observation can be twofold.

On the academic level, it leads to the conclusion that in studying implementation of EU legislation caution in using the term 'implementation' is in order. When implementation is defined by its judicial interpretation, the conclusion is justified that the Safety Data Sheets Directive is perfectly implemented. When implementation is understood in its sociopolitical interpretation, however, implementation is nowhere near perfect. Implementation studies are first of all in need of a clearer demarcation of what exactly is being studied and, second, the SDS case shows the need for more in-depth studies of practical implementation. While transposition studies are numerous, practical implementation to a large extent remains a black box. As Falkner et al. (2005: 343) clearly demonstrate, research into 
practical compliance 'has only uncovered a tip of the iceberg', and we are in need of more information on the substance.

On the policy level, the observation leads to the conclusion that practical implementation requires more of the Commission's attention. When directives are 'only' transposed into national legislation, while they are not applied in practice, the usefulness of legislation becomes questionable. The 'better regulation' campaign of the European Union shows that this is indeed something to be taken into consideration, and the Commission argues that it is giving priority to improving transposition and application of EU law (CEC 2005: 14). One of the solutions identified by the Commission is more use of regulations as they are directly applicable and do not require transposition: 'The use of regulations should be considered in cases with a need of uniform application and legal certainty across the Union' (CEC 2001: 20). The SDS case, however, shows that this line of reasoning does not necessarily hold; problems are at least as likely to occur in the phase of practical implementation as they are in the phase of transposition.

\section{Acknowledgements}

The author would like to thank the two anonymous reviewers for their useful comments.

\section{Notes}

1. OJ L 076, 22/03/1991, pp. 0035-41; amended by Directive 93/112/EC and by Directive 2001/58/EC.

2. The empirical results on the implementation of the Safety Data Sheets Directive are drawn from a policy study conducted for a $\mathrm{PhD}$ dissertation. The information is obtained via a combination of document analysis of primary sources (European and national legislation, guidance material and inspection handbooks), 46 interviews (with a representative of the European Commission (1), national ministries (8), inspectors (19), industry associations (4) and chemical companies (14) in the four member states), and 87 questionnaires (completed by inspectors (31) and chemical companies (56) in the four member states). For more detailed information see Versluis 2003.

3. Falkner et al. (2005: 6) label this stage 'application'.

4. Relevant scholars in this 'eclectic start', as Mastenbroek (2005: 1104) refers to the first wave, are, amongst others, Krislov et al. 1986; Schwarze et al. 1991, 1993; Siedentopf and Ziller 1988.

5. Meier (1999: 5-6) argues that implementation theory can be characterised as 'forty-seven variables that completely explain five case studies' and he proposes that '[a]ny policy scholar who adds a new variable or a new interaction should be required to eliminate two existing variables'. For an overview of explanatory factors used in two decades of EU compliance research, see Mastenbroek 2005: 1105-7.

6. Of the 39 studies analysed by Mastenbroek (2005: 1105-7), 69 per cent focus (mainly) on transposition.

7. On the European market there are a little over 100,000 'existing' substances (a substance consists of one component, for example sulphur) of which it is estimated that approximately 30,000 are produced, marketed and used. The number of preparations 
(a preparation is a compound or solution consisting of two or more pure substances, for example glue or paint) is harder to establish, but as a 'guideline' it is estimated that about 95 per cent of the chemicals on the market are preparations (Versluis 2003: 27).

8. Since 1 January 2002 this inspectorate is incorporated into the general 'VROM-Inspectie' ('Inspectorate of Housing, Spatial Planning and the Environment').

9. According to the Dutch law, four other agencies could be involved in the enforcement of this legislation. The extent to which this happens is so minimal that they are left out of the description.

10. For the purpose of this research, three Länder have been selected to study the enforcement system: North-Rhine Westphalia, Baden-Württemberg and Bavaria.

11. The 'Trading Standards Institute' also has responsibility for the SDS Directive on paper, but does not enforce this topic in practice.

12. Interview with an inspector in the Health and Safety Executive, Northern Region, Sheffield, 6 December 2000.

13. For the purpose of this research, 4 of the 17 Autonomous Communities were selected to study the enforcement system: Andalusia, Catalonia, Madrid and Valencia.

14. These 'ministries' have different names in the different communities, varying from 'Departament de Sanitat I Seguretat Social' in Catalonia, to 'Conselleria de Sanitat' in Valencia, 'Consejería de Sanidad' in Madrid and 'Consejería de Salud' in Andalusia.

15. Interview with a representative of Feique, Madrid, 12 March 2001.

16. For this explanation to hold, the outcomes would have had to indicate considerably stricter enforcement in Germany compared to the United Kingdom and Spain. The SDS case revealed a lack of clear differences in this respect between these countries.

17. Attention, in his view, consists of actor attendance (where do they spend their time?), actor attention (what subjects are they concerned with?) and issue attention (which aspects do they focus on and how do they react?).

18. Interview with an inspector in the Health and Safety Executive, Bootle, 16 November 2000. COMAH is the British legislation that transposed the European Seveso II Directive which regulates the control of major-accident hazards involving dangerous substances.

19. The rule-based enforcement system in Spain might explain why the enforcement is labelled 'semi-active' in Madrid and Andalusia.

\section{References}

Börzel, Tanja A. (2003). Environmental Leaders and Laggards in Europe: Why there is (not) a 'Southern Problem'. Aldershot: Ashgate.

Bovens, Mark, and Stavros Zouridis (2002). 'From Street Level to System Level Bureaucracies. How ICT is Transforming Administrative Discretion and Constitutional Control', unpublished paper, Utrecht School of Governance, Utrecht.

Bursens, Peter (2002). 'Why Denmark and Belgium have Different Implementation Records: On Transposition Laggards and Leaders in the EU', Scandinavian Political Studies, 25:2, $173-95$.

Chayes, Abram, and Antonia Handler Chayes (1993). 'On Compliance', International Organization, 47:2, 175-205.

Checkel, Jeffrey T. (1999). 'Why Comply? Constructivism, Social Norms and the Study of International Institutions', ARENA Working Paper 99/24. Oslo: Advanced Research on the Europeanisation of the Nation-State.

Colchester, Nicholas, and David Buchan (1990). Europe Relaunched: Truths and Illusions on the Way to 1992. London: Hutchinson/Economist Books.

Commission of the European Communities (CEC) (2001). European Governance. A White Paper. COM(2001) 428 final, 25 July, Brussels.

Commission of the European Communities (CEC) (2005). Better Regulation for Growth and Jobs in the European Union. COM(2005) 97, 16 March, Brussels. 
Cowles, Maria Green, James Caporaso and Thomas Risse, eds. (2001). Transforming Europe: Europeanization and Domestic Change. Ithaca, NY: Cornell University Press.

Demmke, Christoph (2001). 'Towards Effective Environmental Regulation: Innovative Approaches in Implementing and Enforcing European Environmental Law and Policy', Jean Monnet Working Paper 5/01. Cambridge, MA: Harvard Law School.

Dimitrakopoulos, Dyonissis G. (2001). 'The Transposition of EU Law: "Post-Decisional" Politics and Institutional Autonomy', European Law Journal, 7:4, 442-58.

Falkner, Gerda, Oliver Treib, Miriam Hartlapp and Simone Leiber (2005). Complying with Europe. EU Harmonisation and Soft Law in the Member States. Cambridge: Cambridge University Press.

From, Johan, and Per Stava (1993). 'Implementation of Community Law: The Last Stronghold of National Control?', in Svein S. Andersen and Kjell A. Eliassen (eds.), Making Policy in Europe. The Europeification of National Policy-Making. London: Sage, 55-67.

Haverland, Markus (1999). National Autonomy, European Integration and the Politics of Packaging Waste. Amsterdam: Thela Thesis.

Héritier, Adrienne, Dieter Kerwer, Christoph Knill, Dirk Lehmkuhl, Michael Teutsch and Anne-Cécille Douillet, eds. (2001). Differential Europe: The European Union Impact on National Policymaking. Lanham, MD: Rowman and Littlefield.

Hill, Michael, and Peter Hupe (2002). Implementing Public Policy. London: Sage.

Inspectie Milieuhygiëne (1999a). 'Handhavingsuitvoeringsmethode. Wet milieugevaarlijke stoffen Integratie Project (WIP)', Den Haag: Ministerie van Volkshuisvesting, Ruimtelijke Ordening en Milieubeheer.

Inspectie Milieuhygiëne (1999b). 'Stoffige Zaken. Eindrapportage van het Wms Integratie Project gedurende de jaren 1997-98', Den Haag: Ministerie van Volkshuisvesting, Ruimtelijke Ordening en Milieubeheer.

Inspectie Milieuhygiëne (2000a). 'Handelskenmerken. Handhavingsactie naar de naleving van een aantal besluiten van de Wms bij chemicaliëngroothandelaren', Den Haag: Ministerie van Volkshuisvesting, Ruimtelijke Ordening en Milieubeheer.

Inspectie Milieuhygiëne (2000b). 'Stof tot nadenken. Verslag van de Controle-actie Wms november 1999-april 2000', Den Haag: Ministerie van Volkshuisvesting, Ruimtelijke Ordening en Milieubeheer.

Kingdon, John W. (1995). Agendas, Alternatives, and Public Policies. New York: Harper Collins.

Knill, Christoph (1997). 'Implementing European Policies: The Impact of National Administrative Traditions', EUI Working Paper 97/56. Florence: European University Institute.

Knill, Christoph, and Andrea Lenschow (1998). 'Coping with Europe: The Impact of British and German Administrations on the Implementation of EU Environmental Policy', Journal of European Public Policy, 5:4, 595-614.

Krislov, Samuel, Claus-Dieter Ehlermann and Joseph Weiler (1986). 'The Political Organs and the Decision-Making Process in the United States and the European Community', in Mauro Cappelletti, Monica Seccombe and Joseph Weiler (eds.), Integration through Law: Methods, Tools and Institutions. Political Organs, Integration Techniques and Judicial Process. Vol. I. Berlin: Walter de Gruyter, 3-110.

La Spina, Antonio, and Giuseppe Sciortino (1993). 'Common Agenda, Southern Rules: European Integration and Environmental Change in the Mediterranean States', in Duncan Liefferink, Philip D. Lowe and Arthur P.J. Mol (eds.), European Integration and Environmental Policy. London: Belhaven Press, 217-36.

Mastenbroek, Ellen (2003). 'Surviving the Deadline. The Transposition of EU Directives in the Netherlands', European Union Politics, 4:4, 371-95.

Mastenbroek, Ellen (2005). 'EU Compliance: Still a 'Black Hole'?', Journal of European Public Policy, 12:6, 1103-20.

Meier, Kenneth J. (1999). 'Are We Sure Lasswell Did It This Way? Lester, Goggin and Implementation Research', Policy Currents, 9:1, 5-8. 
Ministry of Housing, Spatial Planning, and Environment (1998). 'European inspection project "SENSE", The Hague.

Neuhold, Christine (2001). “"Much Ado About Nothing?” Comitology as a Feature of EU Policy Implementation and its Effects on the Democratic Arena', Political Science Series 78. Vienna: Institute for Advanced Studies.

Neyer, Jürgen, and Michael Zürn (2001). 'Compliance in Comparative Perspective. The EU and Other International Institutions', Arbeitspapier 23/01. Bremen: Institut für Interkulturelle und Internationale Studien.

Noordegraaf, Mirko (2000). Attention! Work and Behavior of Public Managers amidst Ambiguity. Delft: Eburon.

Pappas, Spyros A., ed. (1995). National Administrative Procedures for the Preparation and Implementation of Community Decisions. Maastricht: EIPA.

Pressman, Jeffrey L., and Aaron Wildavsky (1973). Implementation: How Great Expectations in Washington are Dashed in Oakland. Berkeley: University of California Press.

Pridham, Geoffrey, and Michelle Cini (1994). 'Enforcing Environmental Standards in the European Union: Is There a Southern Problem?', in Micheal Faure, John Vervaele and Albert Weale (eds.), Environmental Standards in the European Union in an Interdisciplinary Framework. Antwerpen: MAKLU, 251-77.

Roberts, Marilyn, Wayne Wanta and Tzong-Horng Dzwo (2002). 'Agenda Setting and Issue Salience Online', Communication Research, 29:4, 452-65.

Sabatier, Paul A., and Daniel A. Mazmanian (1979). 'Conditions of Effective Implementation: A Guide to Accomplishing Policy Objectives', Policy Analysis, 5:4, 481-504.

Schwarze, Jürgen, Ulrich Becker and Christina Pollack (1991). The 1992 Challenge at National Level: A Community-Wide Joint Research Project on the Realization and Implementation by National Governments and Business of the Internal Market Programme: Reports and Conference Proceedings 1990. Baden-Baden: Nomos.

Schwarze, Jürgen, Ulrich Becker and Christina Pollack (1993). The 1992 Challenge at National Level: A Community-Wide Joint Research Project on the Realization and Implementation by National Governments and Business of the Internal Market Programme: Reports and Conference Proceedings 1991/92. Baden-Baden: Nomos.

Siedentopf, Heinrich, and Jacques Ziller, eds. (1988). Making European Policies Work. The Implementation of Community Legislation in the Member States. Volume I Comparative Syntheses. London: Sage.

Somsen, Han, ed. (1996). Protecting the European Environment: Enforcing EC Environmental Law. London: Blackstone Press Limited.

Tallberg, Jonas (2002). 'Paths to Compliance: Enforcement, Management, and the European Union', International Organization, 56:3, 609-43.

Umweltministerium Baden-Württemberg (2000). 'Inhaltliche Prüfung eines Sicherheitsdatenblattes', unpublished document, Stuttgart.

Versluis, Esther (2003). Enforcement Matters. Enforcement and Compliance of European Directives in Four Member States. Delft: Eburon. 